\title{
Active fraction of clove induces apoptosis via PI3K/Akt/mTOR-mediated autophagy in human colorectal cancer HCT-116 cells
}

\author{
MINGHUA LIU*, GE ZHAO*, DAN ZHANG, WEIXIAO AN, HONGLIN LAI, \\ XIAOFANG LI, SHOUSONG CAO and XIUKUN LIN
}

Department of Pharmacology, School of Pharmacy, Southwest Medical University, Luzhou, Sichuan 646000, P.R. China

Received March 19, 2018; Accepted June 14, 2018

DOI: $10.3892 / \mathrm{ijo} .2018 .4465$

\begin{abstract}
Previous studies by our group have demonstrated that extract of clove exhibits potent anticancer effects in vitro and in vivo. In the present study, the effect of an extracted and isolated active fraction of clove (AFC) on induction of cellular apoptosis in human colorectal cancer HCT-116 cells was investigated by morphological observation, flow cytometry, and western blotting analysis. The results revealed that AFC induced apoptosis of HCT-116 cells. AFC also induced autophagy, demonstrated by increased punctuate microtubuleassociated protein 1A/1B-light chain 3 (LC3) staining, and LC3-II and Beclin-1 protein expression levels. Furthermore, the autophagy inhibitors 3-MA and baflomycin A1 potentiated the pro-apoptotic activity of AFC in HCT-116 cells. AFC also inhibited the phosphorylation of the phosphoinositide 3-kinase/Akt/mechanistic target of rapamycin signaling pathway. The present study may improve the existing understanding of the anticancer mechanisms of clove and provide a scientific rationale for AFC to be further developed as a promising novel anticancer agent for the treatment of colorectal cancer.
\end{abstract}

\section{Introduction}

Colorectal cancer (CRC) is among the most common types of cancer and the third leading cause of cancer-associated mortality worldwide. Therefore, it is an important topic among oncologists and cancer biologists (1-3). Although the mortality

Correspondence to: Professor Xiukun Lin or Professor Shousong Cao, Department of Pharmacology, School of Pharmacy, Southwest Medical University, 319 Zhongshan Road, Jiangyang, Luzhou, Sichuan 646000, P.R. China

E-mail: linxiukun@yahoo.com

E-mail: shousongc@gmail.com

\section{${ }^{*}$ Contributed equally}

Key words: clove, apoptosis, autophagy, coloretal cancer, phosphoinositide 3-kinase/Akt/mechanistic target of rapamycin pathway rate of CRC has decreased significantly with early detection and surgery and chemotherapy treatments, recurrence and drug resistance have become more common (4). Therefore, there is an urgent requirement to develop novel anticancer drugs and/or therapeutic strategies for the treatment of colorectal cancer.

Clove, the dried bud of Syzygium aromaticum, is a traditional medicinal herb widely used in Asian countries. Clove has been indicated to possess various biological properties including anti-infammatory $(5,6)$, antivira $(7)$, antibacterial $(8)$, antioxidant $(8,9)$ and antitumor $(8,10,11)$ activities. Our previous study demonstrated that the active fraction of clove (AFC) was effective against various types of cancer cell, including lung, breast, liver, pancreatic, ovarian and cervical cancer (12). Two components of AFC have been identified as demonstrating cytotoxicity against various types of cancer cells: Oleanonic acid (OA) and eugenol (12). It was also demonstrated that $\mathrm{OA}$ was able to induce apoptosis of cancer cells via the mitochondrial pathway (13). Combination of OA and fluorouracil (5-FU) treatments synergistically potentiated the cytotoxicity of 5-FU against human pancreatic cancer Pan-28 cells (13). AFC was more effective than a single isolated component of OA or eugenol against human colon cancer HT-29 xenografts in vivo (12). However, the mechanistic action of AFC remains unclear. Therefore, the present study had the interesting aim of elucidating the mechanism of action of AFC.

Apoptosis (programmed cell death) is a highly regulated and controlled process and serves a crucial role in the development and treatment of cancer (14-16). Apoptosis occurs through two major molecular pathways, the intrinsic (mitochondrial) and the extrinsic (death receptor-mediated) pathways $(16,17)$. The intrinsic pathway involves the mitochondria and mainly affects the Bcl-2 and caspase families (17). The extrinsic pathways involves death signals, including TNF- $\alpha$ with TNF receptor 1 (TNFR1) and activates caspase- 8 to cleave procaspase-3 into its active form (16). Apoptosis is an important anticancer mechanism and numerous anticancer drugs execute their anticancer activity via induction of apoptosis (18).

Autophagy is a survival-promoting pathway and serves a complicated role in cell development, growth and tumorigenesis to regulate inhibition of cancer cell proliferation or promotion of cancer cell survival (19-22). Numerous anticancer 
agents display antitumor activity via autophagy of cancer cells (23-25). The phosphoinositide 3-kinase/Akt/mechanistic target of rapamycin signaling pathway is a major signal transduction cascade involved in cell proliferation, survival and metabolism, and it serves an important role in the development and therapy of colorectal cancer $(26,27)$. Upregulation of PI3K expression results in the inhibition of apoptosis in colon cancer SW480 cells (28). The PI3K/Akt/mTOR signaling pathway is also an important therapeutic target and a previous study demonstrated that the dual PI3K/mTOR inhibitor, NVP-BEZ235, was effective against colorectal cancer cells in vitro and in vivo (29). The PI3K/Akt/mTOR signaling pathway is also involved in the autophagic process, and activation of the pathway attenuates autophagy in cancer cells. A recent study also demonstrated that $\mathrm{OA}$, one of the main components of AFC, is capable of inducing protective autophagy in cancer cells via the PI3K/Akt/mTOR signaling pathway (30). However, the effect of AFC on autophagy remains unclear. In the present study, AFC-induced autophagic effects were evaluated in human colorectal cancer HCT-116 cells by morphological observation, flow cytometry and western blotting. The results revealed that AFC induced apoptosis via the $\mathrm{PI} 3 \mathrm{~K} / \mathrm{Akt} / \mathrm{mTOR}$-mediated autophagic pathway in colorectal cancer HCT-116 cells.

\section{Materials and methods}

Reagents and antibodies. Rapamycin and 3-methyladenine (3-MA) were purchased from Medchem Express Co., Ltd. (Shanghai, China). Baflomycin A1 (BA) was purchased from Beijing Hua MEIKO Biotechnology Co., Ltd. (Beijing, China). The Annexin V-FITC apoptosis detection kit was purchased from BD Biosciences (San Diego, CA, USA). Cell culture media, DMEM, RPMI-1640, and McCoy's5A were purchased from Gibco (Thermo Fisher Scientific, Inc., Waltham, MA, USA). Cell Counting kit-8 (CCK-8), Hoechst 33258, Ad-mCherry-GFP-LC3B, dimethyl sulfoxide (DMSO), fetal bovine serum (FBS), penicillin, streptomycin, monoclonal antibodies of $\beta$-actin (cat. no. AA128-1), horseradish peroxidase (HRP)-labeled goat anti-rat $\mathrm{IgG}(\mathrm{H}+\mathrm{L})(\# \mathrm{~A} 0216)$ and HRP-labeled goat anti-rabbit $\operatorname{IgG}(\mathrm{H}+\mathrm{L})$ (cat. no. A0208) were purchased from Beyotime Institute of Biotechnology (Shanghai, China). LY294002, the caspase-3 (cat. no. ab32351), caspase-9 (cat. no. ab32539) and Poly(ADP-ribose) polymerase (PARP; cat. no. ab191217) antibodies were purchased from Abcam (Cambridge, UK). LC3B (cat. no. 3868), Beclin-1 (cat. no. 3495), PI3K (cat. no. 4292), p-PI3K at Tyr458 (cat. no. 4228), Akt (cat. no. 9272), p-Akt at Ser473 (cat. no. 9271), mTOR (cat. no. 2972) and p-mTOR at Ser2448 (cat. no. 2971) were purchased from Cell Signaling Technology, Inc. (Danvers, MA, USA). Insulin-like growth factor-I (IGF-I) was purchased from R\&D Systems, Inc. (Minneapolis, MN, USA).

Cell culture. The human colorectal carcinoma cell lines, HCT-116, SW620, HCT8, HT29 and LoVo were purchased from the American Type Culture Collection (ATCC; Manassas, VA, USA). Cells were grown in RPMI-1640, DMEM or McCoy's5A (Gibco; Thermo Fisher Scientific, Inc.) culture medium containing $10 \%$ heat-inactivated $\mathrm{FBS}, 100 \mathrm{U} / \mathrm{ml}$ penicillin and $100 \mathrm{mg} / \mathrm{ml}$ streptomycin at $37^{\circ} \mathrm{C}$ in $5 \% \mathrm{CO}_{2}$. Cells in the logarithmic phase were routinely renewed with fresh medium every 2-3 days.

Extraction, isolation and characterization of individual compounds with cytotoxic activity. Air-dried, powdered clove was purchased from Qingdao Company of Traditional Chinese Medicine (Qingdao, Shandong, China). The isolation and extraction of clove was performed as previously described (31). Briefly, $10.0 \mathrm{~kg}$ powdered clove was hydrated with $95 \%$ ethanol at room temperature for $72 \mathrm{~h}$. Subsequent to filtration, the solution was concentrated to generate an ethanol extract and the extract was further extracted with ethyl acetate at $60^{\circ} \mathrm{C}$ for $2 \mathrm{~h}$, and the supernant was concentrated using a vacuum rotary evaporator (Yamato Sci., Tokyo, Japan). The ethyl acetate extract of clove (EAEC) was fractionated using silica gel column chromatography (CC; 200 and 400 mesh) and Sephadex LH-20 CC. The resulting fraction was defined as active fraction from clove (AFC). The purity was characterized by the Department of Chemistry and Molecular Engineering at Qingdao University (Qingdao) using ${ }^{1} \mathrm{H}$ - and ${ }^{13} \mathrm{C}-\mathrm{NMR}$ analysis, confirming that ACF contained three main compounds, including eugenol (32.32\%) and oleanonic Acid (23.60). AFC underwent a comprehensive residue screen for 172 pesticides by the Pacific Agricultural Laboratory (Portland, OR, USA) and no pesticides were detected. Similarly, AFC was analyzed for heavy metal content by Avomeen Analytical Services (Ann Arbor, MI, USA) and no heavy metal was detected.

Drug preparation and treatment. AFC was diluted with cell culture medium to final concentrations of 25, 50, 100, 200 and $400 \mu \mathrm{g} / \mathrm{ml}$ for the treatment of HCT-116 cells for 24, 48 or $72 \mathrm{~h}$. The PI3K inhibitor, LY294002, and the autophagylysosomal inhibitor, BA, were dissolved in DMSO and diluted with culture medium. The final concentration of DMSO in the test solutions was $<0.1 \%$. This concentration of DMSO did not cause any adverse responses in cells. 3-MA was dissolved in heated sterile double distilled water to achieve a $100 \mathrm{mM}$ stock solution, and was then diluted with culture medium for a final concentration of $2 \mathrm{mM}$. IGF-I (a PI3K activator) was reconstituted to $10 \mu \mathrm{g} / \mathrm{ml}$ in sterile PBS, and diluted with culture medium for a final concentration of $50 \mathrm{ng} / \mathrm{ml}$. HCT-116 cells were pretreated with $10 \mu \mathrm{M} \mathrm{LY} 294002,1 \mathrm{nM}$ BA, 2 mM 3-MA or $50 \mathrm{ng} / \mathrm{ml}$ IGF-I for $1 \mathrm{~h}$, then further treated with $100 \mu \mathrm{g} / \mathrm{ml}$ AFC for $48 \mathrm{~h}$. Cells were treated with fresh medium without serum as a vehicle control.

Cell viability assay. Cell viability was determined by CCK- 8 assay as previously described (12). Briefly, cells at $80-90 \%$ confluency were seeded in 96-well plates at a density of $5 \times 10^{3}$ cells/well. After a 24 -h incubation $25,50,100,200$ or $400 \mu \mathrm{g} / \mathrm{ml} \mathrm{AFC}$, or vehicle control, was added to the wells. After 24,48 or $72 \mathrm{~h} 10 \%$ CCK- 8 reagent $(10 \mu \mathrm{l} /$ well) was added and incubated for $1 \mathrm{~h}$ at $37^{\circ} \mathrm{C}$. The absorbance value (optical density; OD) was measured at a wavelength of $450 \mathrm{~nm}$ with a SpectraMAX M3 microplate spectrophotometer (Molecular Devices Corporation, Sunnyvale, CA, USA) and the cell viability ratio was calculated using the following formula: Cell viability rate $=(\mathrm{OD}$ of the experimental group/OD of the control group) $\mathrm{x} 100 \%$. The half maximal inhibitory concentration $\left(\mathrm{IC}_{50}\right)$ values were determined using a nonlinear best fit method 
by GraphPad Prism 6 (GraphPad Software, Inc., La Jolla, CA, USA). All experiments were performed 3 times in triplicate.

GFP-LC3 transfection. HCT-116 cells were seeded onto coverslips in a 24 -well plate at a density of $5 \times 10^{4}$ cells/well and were transfected with Ad-mCherry-GFP-LC3B. Following $24 \mathrm{~h}$ of culture, the cells were treated with AFC $(100 \mu \mathrm{g} / \mathrm{ml})$ or medium (control) for $48 \mathrm{~h}$ then fixed with $4 \%$ polyoxymethylene and observed with an EVOS ${ }^{\mathrm{TM}}$ FL Imaging system (AMF4300; Thermo Fisher Scientific Inc.). Autophagic cells presenting $\geq 5$ mRFP-GFP-LC3 dots were counted. All experiments were performed 3 times in triplicate.

Apoptotic assay of HCT-116 cells by Hoechst 33258 staining. Morphological assessment of apoptotic cells was analyzed using Hoechst 33258 staining as previously described (31). Briefly, HCT-116 cells were seeded in a 24 -well plate at a density of $5 \times 10^{4}$ cells/well. Following culture for $24 \mathrm{~h}$, the cells were treated with 25,50 or $100 \mu \mathrm{g} / \mathrm{ml} \mathrm{AFC} \mathrm{or} \mathrm{the} \mathrm{same}$ volume of vehicle control. Following incubation for another $48 \mathrm{~h}$, the cells were fixed with $4 \%$ paraformaldehyde for $10 \mathrm{~min}$ at room temperature, and the medium was removed and washed with PBS for $15 \mathrm{~min}$. The cells were treated with $10 \mu \mathrm{g} / \mathrm{ml}$ Hoechst 33258 staining at room temperature for $10 \mathrm{~min}$, and washed with PBS for $15 \mathrm{~min}$ in the dark to reduce background. The morphology of the cells was visualized and photographed under a DMR fluorescence microscope at x400 magnification (Leica Microsystems $\mathrm{GmbH}$, Wetzlar, Germany) using fluorescence excitation at $340 \mathrm{~nm}$. The apoptotic index was calculated using the following formula: Apoptotic index $=$ apoptotic cell number/total cell number $\mathrm{x} 100 \%$. A minimum of 4 fields of view of each well, containing $\geq 500$ cells, were required to calculate the rate of apoptosis. All experiments were performed 3 times in triplicate.

Observation of autophagosomes by transmission electron microscopy. HCT-116 cells were seeded in a 24-well plate at a density of $5 \times 10^{4}$ cells/well. Following $24 \mathrm{~h}$ of culture, the cells were treated with 25,50 and $100 \mu \mathrm{g} / \mathrm{ml} \mathrm{AFC} \mathrm{or} \mathrm{the} \mathrm{equiva-}$ lent volume of medium (vehicle control) for $48 \mathrm{~h}$. The cells were collected by trypsinization and washed twice with PBS, then fixed in $2.5 \%$ glutaraldehyde for $90 \mathrm{~min}$ and post-fixed in $1 \%$ osmium tetraoxide for $30 \mathrm{~min}$ at room temperature. Subsequent to 3 washes with PBS, the cells were progressively dehydrated in an ascending alcohol series (50, 70, 95 and $100 \%$ ), and embedded in Epon resin. The ultrathin sections were contrasted with uranyl acetate and lead citrate for electron microscopy observation. The ultrastructure of the cells was then examined under a transmission electron microscope (JEM-1230; JEOL, Ltd., Tokyo, Japan). All experiments were performed 3 times in triplicate.

Apoptotic assay of HCT-116 cells with Annexin V-FITC/PI and flow cytometry. AFC-induced apoptosis in HCT-116 cells was also evaluated by flow cytometry with Annexin V-FITC apoptosis detection kit (cat. no. 556547BD Pharmingen; BD Biosciences), according to the manufacturer's protocol. Briefly, HCT-116 cells at $80-90 \%$ confluency were seeded in 6 -well plates at a density of $4 \times 10^{5}$ cells/well and cultured for $24 \mathrm{~h}$. Then, the cells were treated with $100 \mu \mathrm{g} / \mathrm{ml}$ AFC or vehicle control for $48 \mathrm{~h}$. After treatment, the cells were harvested by cryogenic centrifugation at $4^{\circ} \mathrm{C}, 1,500 \mathrm{x}$ g for $5 \mathrm{~min}$ and washed twice with $4^{\circ} \mathrm{C}$ PBS. The cells were resuspended in $1 \mathrm{X}$ binding buffer at a concentration of $1 \times 10^{6}$ cells $/ \mathrm{ml}$. A total of $100 \mu \mathrm{l}$ of the solution $\left(1 \times 10^{5}\right.$ cells) was transferred to a 5-ml culture tube, and $5 \mu 1$ Annexin V-FITC and $5 \mu 1 \mathrm{PI}$ were successively added to the cells and incubated at room temperature in the dark for $15 \mathrm{~min}$. The quantity of stained cells was analyzed using a flow cytometer (FACSCalibur; BD Biosciences, Franklin Lakes, NJ, USA). All experiments were performed 3 times in triplicate.

Western blotting analysis. HCT-116 cells were seeded at a density of $4 \times 10^{5}$ cells/well in 6 -well plates, and the culture medium ( $2 \mathrm{ml})$ was replaced after $24 \mathrm{~h}$ in culture, with 25,50 or $100 \mu \mathrm{l} / \mathrm{ml} \mathrm{AFC}$, or vehicle control for $24 \mathrm{~h}$ prior to harvesting. The cells were lysed on ice with radioimmunoprecipitation assay buffer [0.5\% NP-40, $50 \mathrm{mM}$ Tris- $\mathrm{HCl}, 120 \mathrm{mM} \mathrm{NaCl}$, $1 \mathrm{mM}$ EDTA, $0.1 \mathrm{mM} \mathrm{Na} \mathrm{VO}_{4}, 1 \mathrm{mM} \mathrm{NaF}, 1 \mathrm{mM}$ phenylmethylsulfonyl fluoride (PMSF) and $1 \mu \mathrm{g} / \mathrm{ml}$ leupeptin, $\mathrm{pH}$ 7.5] for $30 \mathrm{~min}$ in the presence of PhosSTOP (Roche Molecular Systems, Inc., Basel, Switzerland) with PMSF and then centrifuged at $9600 \mathrm{x} \mathrm{g}$ for $20 \mathrm{~min}$ at $4^{\circ} \mathrm{C}$. The supernatant was collected and stored in aliquots at $-80^{\circ} \mathrm{C}$ until analysis. Protein concentrations were determined using BCA protein assay kit (Beyotime Institution of Biotechnology, Shanghai, China) and equalized prior to loading. Equal amounts of protein $(40 \mu \mathrm{g})$ were separated by $15 \%$ SDS-PAGE and blotted onto polyvinylidene fluoride membranes (EMD Millipore, Billerica, MA, USA). Following blocking with 5\% non-fat dry milk or bovine serum albumin in $1 \mathrm{X}$ Tris-buffered saline with Tween (TBST; $20 \mathrm{mM}$ Tris- $\mathrm{HCl}, 150 \mathrm{mM} \mathrm{NaCl}$ and $0.05 \%$ Tween-20) for $1 \mathrm{~h}$ at room temperature, the membranes were incubated with primary antibodies at a dilution of 1:1,000 (caspase-9, PARP, LC3B, Beclin-1, PI3K, p-PI3K at Tyr458, Akt, p-Akt at Ser473, mTOR, p-mTOR at Ser2448) and $1 ; 5,000$ ( $\beta$-actin and caspase- 3 ) at $4^{\circ} \mathrm{C}$ overnight. Then, the membranes were incubated secondary antibodies at a dilution of 1:2,000 at room temperature for $1 \mathrm{~h}$. $\beta$-actin was used as a loading control. Following 3 washes in TBST, the membranes were developed by incubation with ECL Western detection reagents (Thermo Fisher Scientific Inc.). The specific protein bands were visualized using a chemiluminescence reagent (EMD Millipore) and imaged using a VersaDoc imaging system (Bio-Rad Laboratories, Hercules, CA, USA). All experiments were performed three times in triplicate. The relative protein expression was quantified by Image $\mathbf{J}$ software (National Institutes of Health, Bethesda, ML, USA). For each sample, the grayscale value of each band was normalized to that of corresponding $\beta$-actin and the ratio of LC3-II/I was calculated using the normalized value of LC3-II/LC3-I.

Statistical analysis. All experiments were repeated $\geq 3$ times. Data were analyzed using SPSS 19.0 statistical software (IBM Corporation, Armonk, NY, USA) and expressed as the mean \pm standard deviation. One-way analysis of variance and Tukey's test were used to compare the means among groups. $\mathrm{P}<0.05$ was considered to indicate a statistically significant difference, and highly significant differences were indicated by $\mathrm{P}<0.01$ and $\mathrm{P}<0.001$. 


\section{Results}

AFC inhibits the proliferation of colorectal cancer cells. We initially investigated the effects of AFC on various types of human colorectal cancer cells using a CCK- 8 assay. The results demonstrated that AFC was able to significantly inhibit proliferation of HCT116, HT-29, SW620, HCT8 and LoVo cells (Fig. 1; Table I). Compared with other cells, HCT116 cells were the most sensitive to AFC. Therefore, HCT116 cells were selected for use in subsequent experiments to investigate the potential mechanisms of the effect AFC in human colorectal cancer cells.

AFC inhibits cell viability and induces apoptosis of HCT-116 cells. The effects of AFC on cell viability of human colorectal cancer HCT-116 cells was investigated by CCK-8 assay. The results demonstrated that AFC inhibited the viability of HCT-116 cells in a dose- and time-dependent manner (Fig. 2A and B). Next, the effect of AFC on the induction of apoptosis of HCT-116 cells was investigated by Hoechst 33258 staining, which is commonly used to detect cell apoptosis by observation of chromatin condensation under a fluorescence microscope (31). As demonstrated in Fig. 2C, following treatment with AFC (25, 50 and $100 \mu \mathrm{g} / \mathrm{ml}$ ) for $48 \mathrm{~h}$, the cells exhibited typical apoptotic morphological features, including chromatin condensation, nuclear shrinkage and the formation of apoptotic bodies. Annexin V is a sensitive method for detection of early apoptosis of cancer cells by using fluorescein (FITC) as fluorescent probe (32). Therefore, the rate of apoptosis of HCT-116 cells was investigated by flow cytometric analysis using Annexin V-FITC/PI double staining. The results demonstrated that the percentage of apoptotic cells increased when HCT-116 cells were treated with AFC compared with control (Fig. 2D and E). To study the underlying mechanism of AFC-induced apoptosis, the cleavage of PARP, caspase-3, and caspase- 9 was analyzed by western blotting. As demonstrated in Fig. 2F and G, AFC cleaved PARP, pro-caspase- 3 and pro-caspase- 9 into their active forms. These data indicate that AFC inhibits cell viability through inducing apoptosis of HCT-116 cells.

AFC induces autophagy in HCT-116 colorectal cancer cells. To study AFC-induced autophagy, the autophagic flow of LC3-puncta was firstly determined. HCT-116 cells were transfected with Ad-mCherry-GFP-LC3B and GFP-LC3 puncta were observed under a fluorescence microscope. As indicated by Fig. 3A, fluorescence of GFP-LC3 puncta was frequently observed in HCT-116 cells treated with AFC, whereas the cells treated with vehicle control exhibited a relatively homogeneous LC3 expression pattern. In addition, a large number of autophagic bodies and autophagy-lysosomes were observed in HCT-116 cells treated with AFC (Fig. 3B) using transmission electron microscopy.

It has been well established that the microtubule-associated protein $1 \mathrm{~A} / 1 \mathrm{~B}$-light chain 3 (LC3) is a central protein in the autophagy pathway and closely associated with autophagosome appearance. Thus, it serves as a reliable marker to monitor autophagy (33). Beclin-1 was the first gene identified to induce autophagy (34). Therefore, the effect of AFC on the expression of LC3 and Beclin-1 was next investigated. As demonstrated by Fig. 3C-E, the expression levels of LC3-II and Beclin-1 in HCT-116 cells were significantly increased
Table $\mathrm{I}$. $\mathrm{IC}_{50}$ of active fraction of clove in terms of proliferation of various cell lines.

\begin{tabular}{lll}
\hline Cell line & \multicolumn{1}{c}{ Tumor type } & $\begin{array}{c}\mathrm{IC}_{50} \mu \mathrm{g} / \mathrm{ml} \\
\text { (mean } \pm \text { standard } \\
\text { deviation) }\end{array}$ \\
\hline HCT116 & Human colorectal cancer cell & $113.5 \pm 7.83$ \\
SW620 & Human colorectal cancer & $174.9 \pm 9.52$ \\
HCT8 & Human colorectal cancer & $211.7 \pm 7.29$ \\
HT29 & Human colorectal cancer & $232.3 \pm 15.42$ \\
LoVo & Human colorectal cancer & $280.9 \pm 12.61$ \\
\hline
\end{tabular}

$\mathrm{IC}_{50}$, half maximal inhibitory concentration.

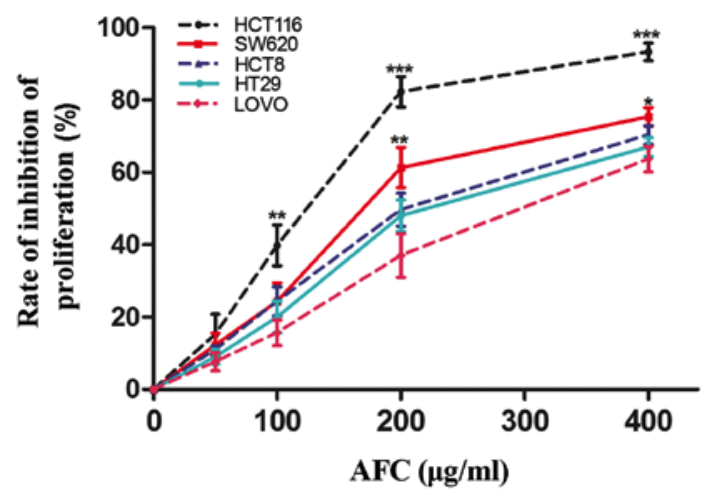

Figure 1. The human colorectal cancer cell lines, HCT-116, SW620, HCT8, HT29 and LoVo, were incubated with $0-400 \mu \mathrm{g} / \mathrm{ml}$ AFC for $48 \mathrm{~h}$. Inhibition of cell viability was measured by cell counting kit- 8 assay. All data are representative of 3 independent experiments (mean \pm standard deviation). ${ }^{*} \mathrm{P}<0.05$, ${ }^{* *} \mathrm{P}<0.01$ and ${ }^{* * *} \mathrm{P}<0.001$ vs. LoVo group. AFC, active fraction of clove.

by AFC in a dose- and time-dependent manner. These data indicated that AFC treatment not only results in apoptosis, but also induces autophagy in HCT-116 cells.

Inhibition of autophagy enhances AFC-induced apoptosis in HCT-116 cells. It has been documented that autophagy could facilitate cell survival in adverse microenvironments and that inhibition of autophagy leads to increased cytotoxicity and induction of apoptosis (35). The effect of inhibition of autophagy on apoptosis induced by AFC in HCT-116 cells was investigated using 2 inhibitors, 3-MA and BA. 3-MA suppresses class III phosphatidylinositol 3-kinase (PI3K), essential for the initiation of the early stages of autophagy (36), while BA, an inhibitor of the vacuolar-type ATPase, inhibits the fusion of autophagosomes with lysosomes, preventing autophagic degradation (37). As demonstrated in Fig. 4A, cell viability was significantly decreased in HCT-116 cells treated with the combination of AFC $(100 \mu \mathrm{g} / \mathrm{ml})$ and 3-MA $(2 \mathrm{mM})$ or BA $(1 \mathrm{nM})$. The resulting cell viability was $40.33 \pm 2.52$ and $54.34 \pm 4.04 \%$, respectively, compared with $73.25 \pm 5.13 \%$ for cells treated with AFC alone. This result indicated that the inhibitory effect of AFC on HCT-116 cell proliferation was enhanced by autophagic inhibitors of 3-MA and BA.

Recent studies suggest that increased LC3 expression could reflect either increased autophagosome formation, due 

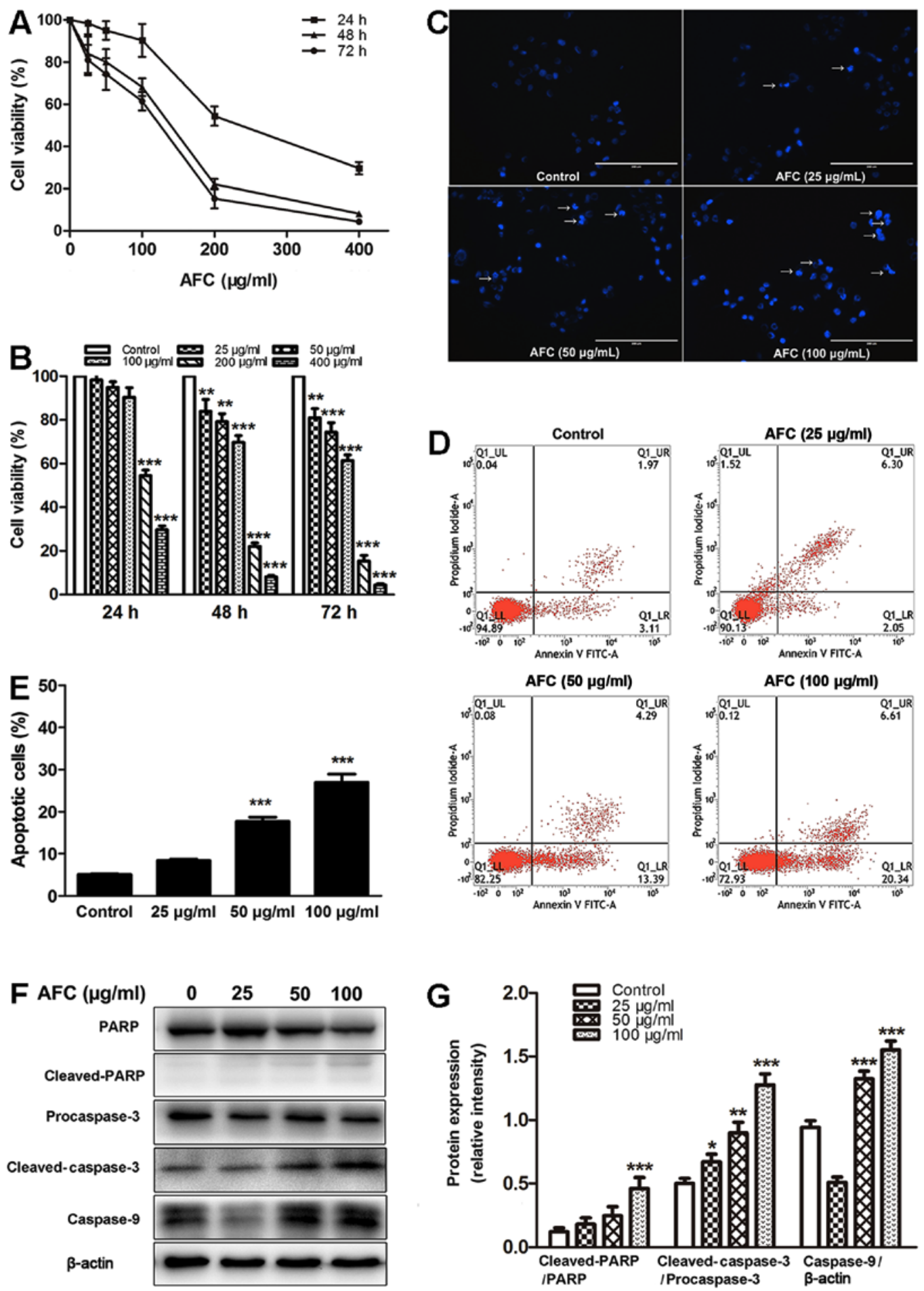

Figure 2. Effects of AFC on cell viability and apoptosis of HCT-116 cells. (A) HCT-116 cells were treated with AFC and cell viability was analyzed by cell counting kit-8 assay. (B) The percentage of cell viability quantified by a histogram for 3 independent experiments (mean \pm standard deviation). (C) Hoechst 33258 staining was used to detect apoptosis, indicated by arrows (x200, magnification). (D) HCT-116 cells were treated with 25,50 or $100 \mu \mathrm{g} / \mathrm{ml} \mathrm{AFC} \mathrm{for} 48 \mathrm{~h}$, and apoptosis was determined by flow cytometry. (E) The percentage of apoptotic cells quantified by a histogram for 3 independent experiments (mean \pm standard deviation). (F) Cleavage of PARP, caspase-3 and caspase-9 was detected by western blotting, using actin as a loading control. (G) Quantification of western blotting results. All data are expressed as mean \pm standard deviation of 3 independent experiments in triplicate. ${ }^{*} \mathrm{P}<0.05,{ }^{* *} \mathrm{P}<0.01$ and ${ }^{* * *} \mathrm{P}<0.001$ vs. vehicle control. AFC, active fraction of clove; PARP, Poly (ADP-ribose) polymerase.

to increased autophagic activity, or reduced autophagosome turnover (33). Therefore, the effects of AFC on LC3 expression in the presence of 3-MA or BA were also studied. As demonstrated in Fig. 4B, 2 mM 3-MA decreased the expression of LC3, but $1 \mathrm{nM}$ BA increased the level of LC3 expression. The opposite effects of 3-MA and BA on LC3 are associated with blocking autophagy at different stages: 3-MA inhibits autophagosome formation, whereas BA prevents degradation of LC3 in autophagolysosomes and in turn increases the LC3 expression level (38). Additionally, 3-MA significantly decreased the LC3 expression induced by AFC, whereas BA increased the LC3 expression induced by AFC treatment (Fig. 4B). These data 


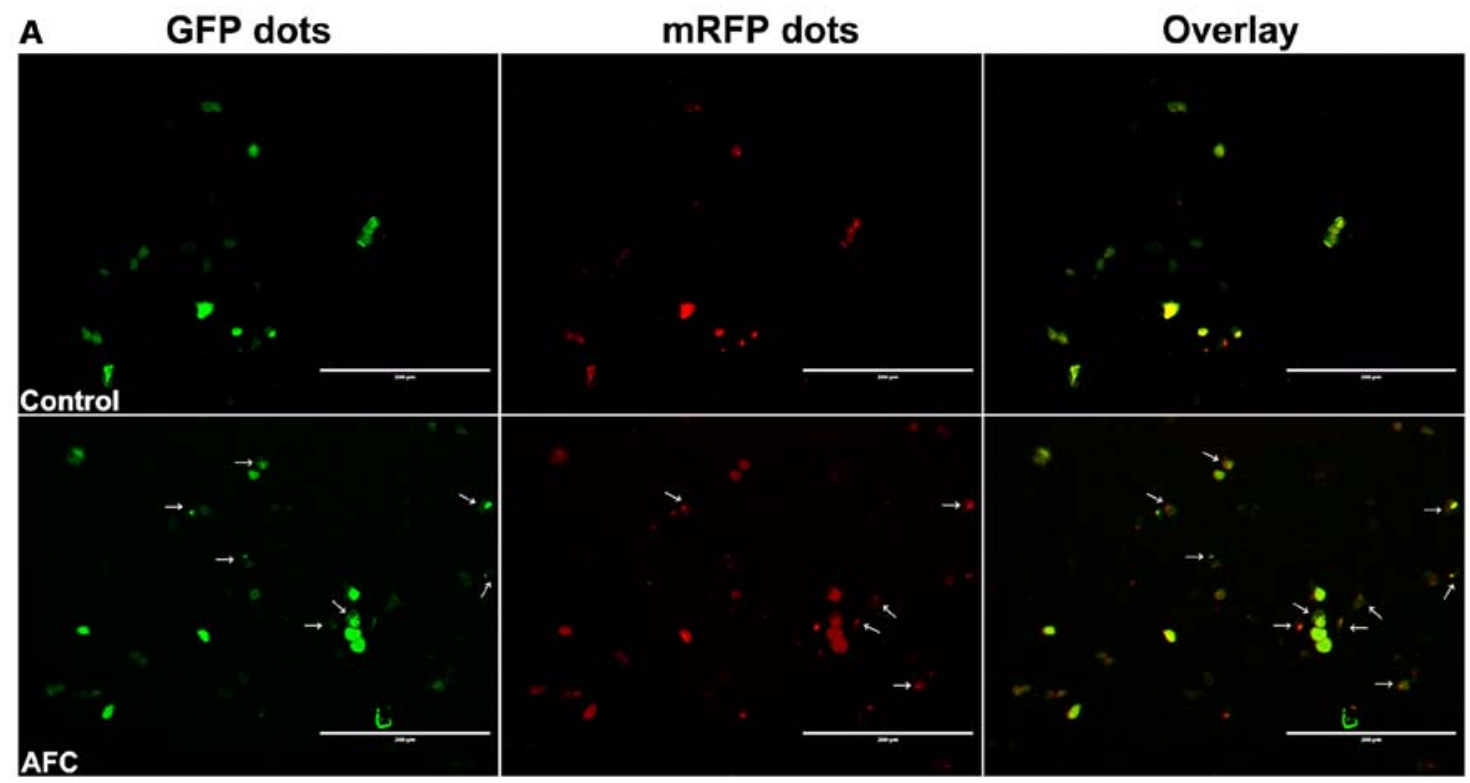

B

Control

$\operatorname{AFC}(100 \mu \mathrm{g} / \mathrm{ml})$

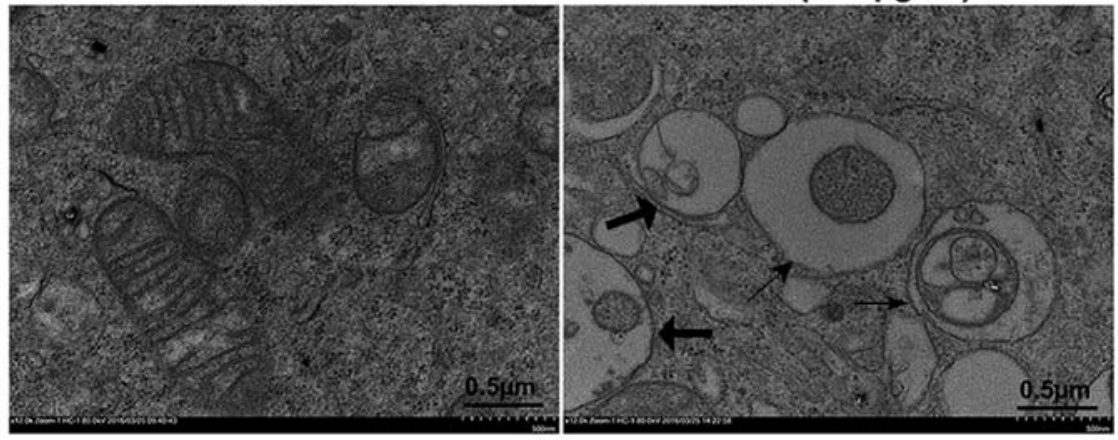

C

AFC $(\mu \mathrm{g} / \mathrm{ml}) \quad 0 \quad 25 \quad 50 \quad 100$

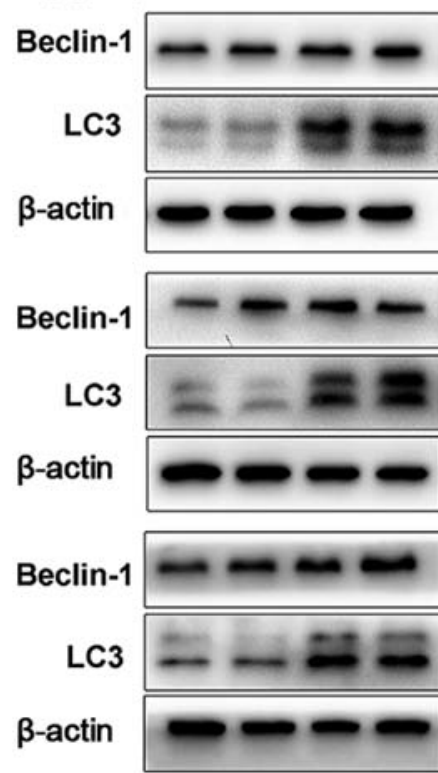

D

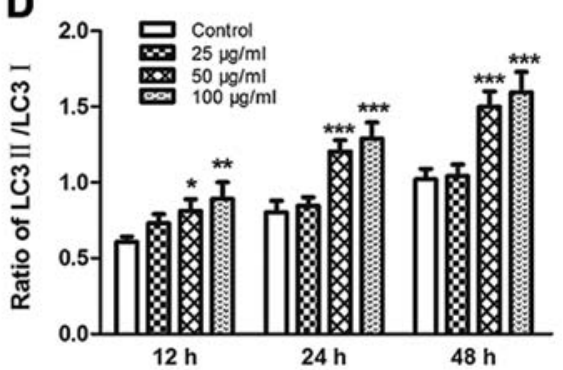

$24 \mathrm{~h}$

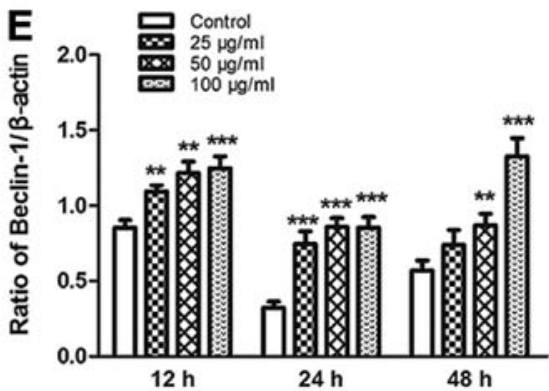

Figure 3. AFC induces autophagy in HCT-116 cells. (A) Stable expression of GFP-LC3 was observed under a fluorescence microscope in HCT-116 cells following treatment with $100 \mu \mathrm{g} / \mathrm{ml} \mathrm{AFC} \mathrm{for} 48 \mathrm{~h}$. Arrows indicate autophagic cells. (B) Autophagy body (thin arrows) and autophagy-lysosome (thick arrows) were observed in HCT-116 cells under a transmission electron microscope (x400, magnification), following treatment with $100 \mu \mathrm{g} / \mathrm{ml} \mathrm{AFC}$ for 48 h. (C) Expression of LC3 and Beclin-1 in HCT-116 cells. (D) Quantification of the LC3-II/I protein expression ratio, using actin as a loading control (E) Quantification of Beclin-1 protein expression, using actin as a loading control. All data are expressed as the mean \pm standard deviation of 3 independent experiments in triplicate. ${ }^{*} \mathrm{P}<0.05,{ }^{* *} \mathrm{P}<0.01$ and ${ }^{* * * *} \mathrm{P}<0.001$ vs. vehicle control. AFC, active fraction of clove; GFP, green fluorescent protein; LC3, microtubuleassociated proteins $1 \mathrm{~A} / 1 \mathrm{~B}$ light chain 3 ; mRFP, monomeric red fluorescent protein. 
A

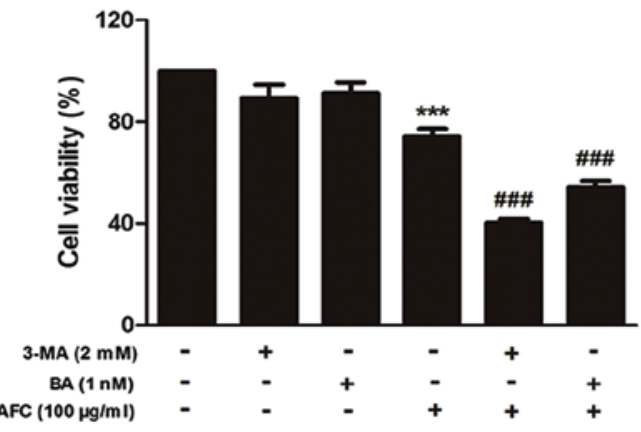

B

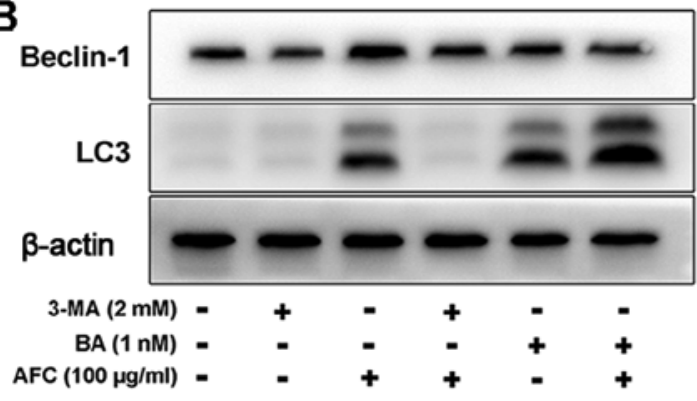

C

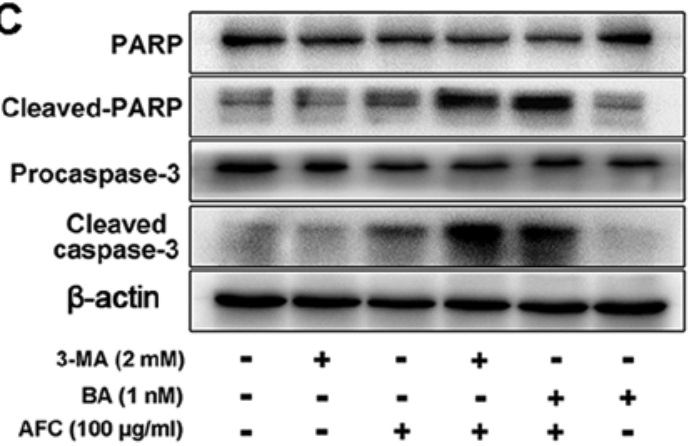

D

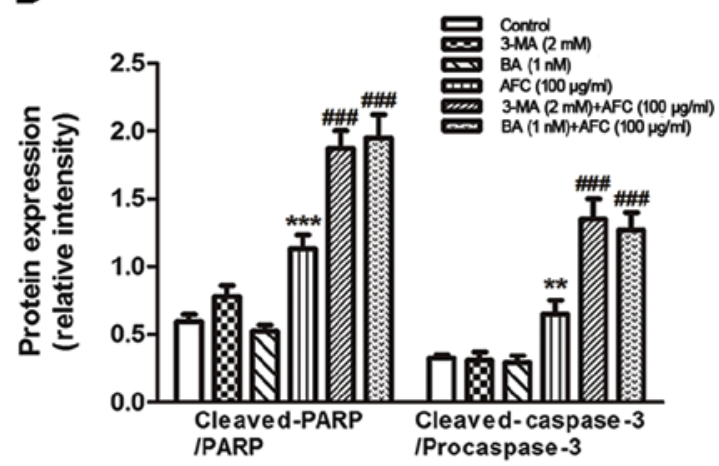

E
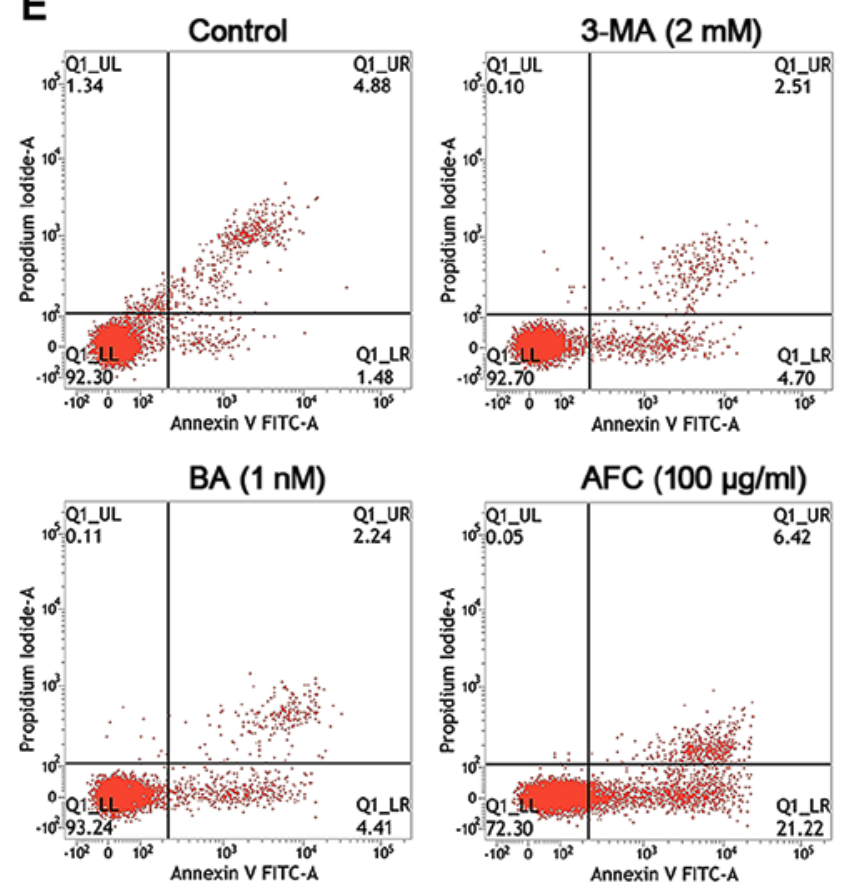

3-MA (2 mM)+AFC $(100 \mu \mathrm{g} / \mathrm{ml})$
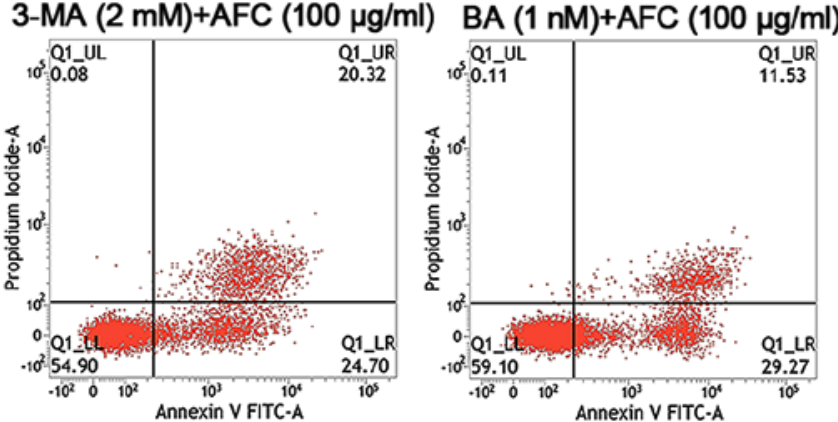

$\mathbf{F}$

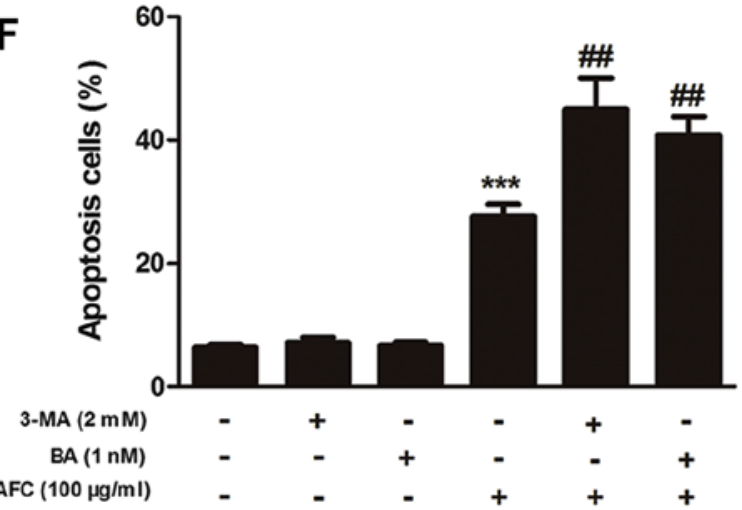

Figure 4. Inhibition of autophagy enhances apoptosis induced by AFC in HCT-116 cells. (A) The effect of 3-MA and BA on cell viability induced by AFC in HCT-116 cells. Cells were treated with $100 \mu \mathrm{g} / \mathrm{ml}$ AFC for $48 \mathrm{~h}$ with or without pretreatment with $2 \mathrm{mM} 3-\mathrm{MA}$ or $1 \mathrm{nM}$ BA for $1 \mathrm{~h}$. (B) The protein expression levels of LC3 and Beclin-1 proteins in HCT-116 cells. Cells were treated with $100 \mu \mathrm{g} / \mathrm{ml}$ AFC for $48 \mathrm{~h}$ with or without pretreatment of $2 \mathrm{mM} 3-\mathrm{MA}$ or $1 \mathrm{nM}$ BA for $1 \mathrm{~h}$. (C) The protein expression levels of cleaved caspase-3 and PARP. Cells were treated with $100 \mu \mathrm{g} / \mathrm{ml}$ AFC for $48 \mathrm{~h}$ with or without pretreatment of $2 \mathrm{mM} 3-\mathrm{MA}$ or $1 \mathrm{nM}$ BA for $1 \mathrm{~h}$. (D) Quantification of western blotting results. (E) The apoptotic ratios of HCT-116 cells analyzed by Annexin V-FITC/PI double staining and flow cytometry. Cells were treated with $100 \mu \mathrm{g} / \mathrm{ml}$ AFC for $48 \mathrm{~h}$ with or without pretreatment with 2 mM $3-\mathrm{MA}$ or $1 \mathrm{nM}$ BA for $1 \mathrm{~h}$. (F) The percentage of apoptotic cells represented by a histogram. Results are expressed as the mean \pm standard deviation, and the experiment was performed in triplicate. ${ }^{*} \mathrm{P}<0.05,{ }^{* *} \mathrm{P}<0.01$ and ${ }^{* * *} \mathrm{P}<0.001$ vs. vehicle control. ${ }^{\# \#} \mathrm{P}<0.01$ and ${ }^{\# \#} \mathrm{P}<0.001$ vs. AFC alone. AFC, active fraction of clove; 3 -MA, 3 -methyladenine; BA, Baflomycin A1; LC3, microtubule-associated proteins 1A/1B light chain 3; PARP, Poly (ADP-ribose) polymerase; PI, propridium iodide.

suggested that 3-MA and BA inhibited autophagy induced by AFC at different stages.

Furthermore, the effect of AFC on the expression of apoptotic genes in the presence of 3-MA or BA was determined.
The expression of cleaved-PARP and cleaved-caspase-3 were increased significantly with combined treatment of AFC and 3-MA or BA compared with either AFC, 3-MA or BA alone in HCT-116 cells $(\mathrm{P}<0.05$; Fig. 4C and D). Similar effects were 
A

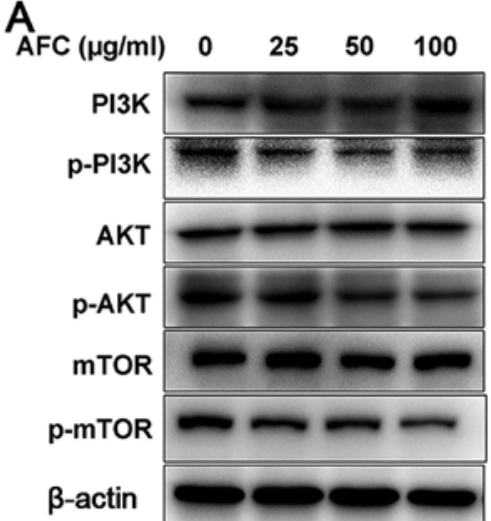

C

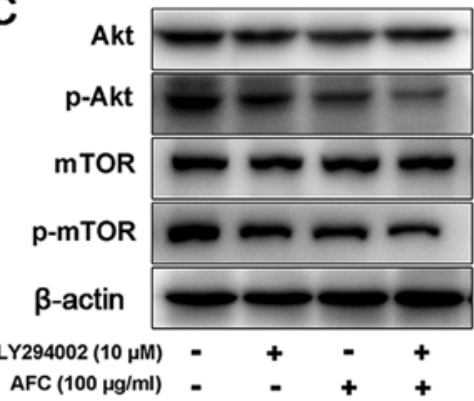

$E$
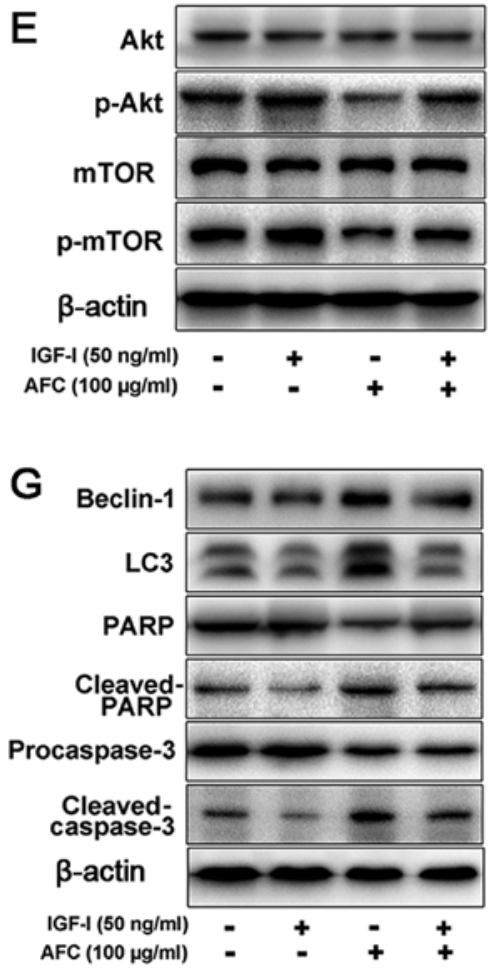

B
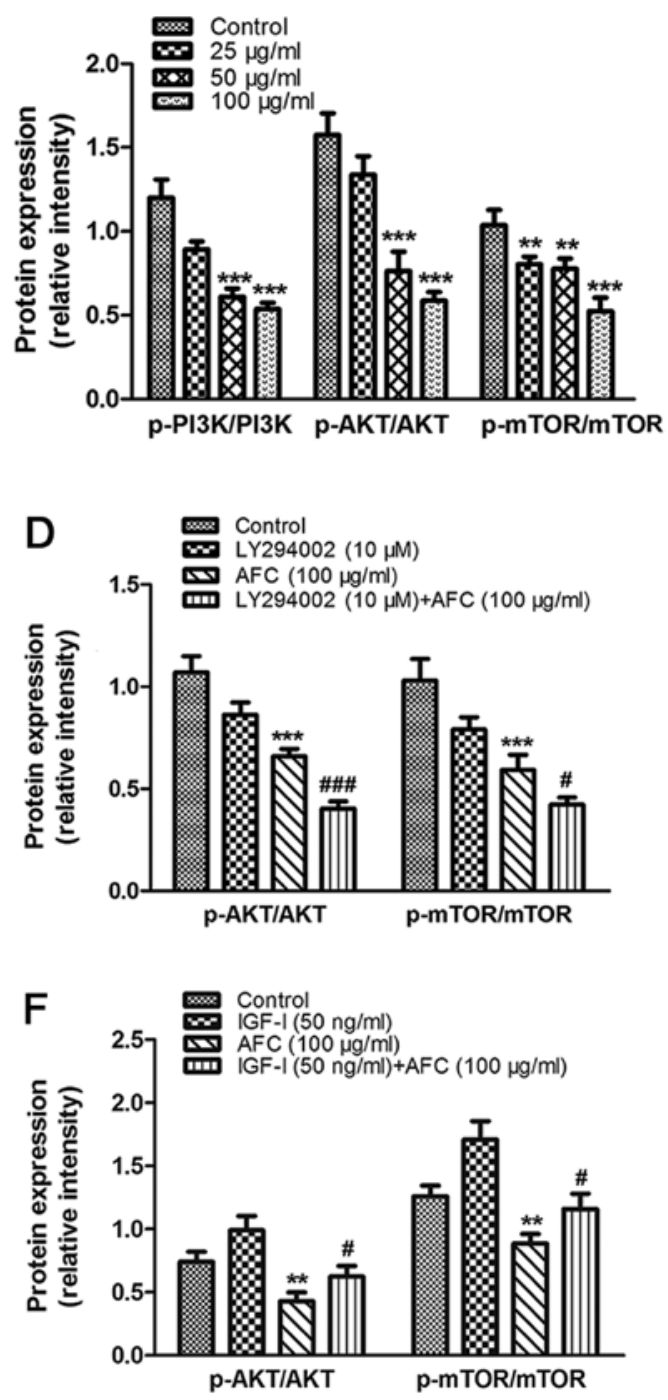

$\mathrm{H}$

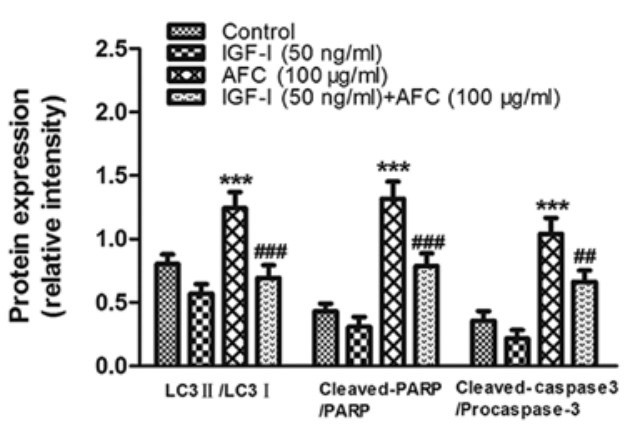

Figure 5. AFC inhibits activation of the PI3K/Akt/mTOR signaling pathway. (A) The protein expression levels of phospho-PI3K, phospho-Akt and phosphomTOR in HCT-116 cells following treatment with 25,50 or $100 \mu \mathrm{g} / \mathrm{ml}$ AFC for $48 \mathrm{~h}$. (B) The intensities of bands were quantified by densitometric analysis. (C) The protein expression levels of phospho-Akt and phospho-mTOR in HCT-116 cells following treatment with $100 \mu \mathrm{g} / \mathrm{ml} \mathrm{AFC}$ with or without $10 \mu \mathrm{M}$ LY294002 for 48 h. (D) Quantification of the western blotting results. (E) The expression levels of phospho-Akt and phospho-mTOR in HCT-116 cells following treatment with $100 \mu \mathrm{g} / \mathrm{ml}$ AFC with or without $50 \mathrm{ng} / \mathrm{ml} \mathrm{IGF-I} \mathrm{for} 48 \mathrm{~h}$. (F) Quantification of the western blotting results. (G) The expression levels of LC3, Beclin-1, caspase-3 and PARP protein in HCT-116 cells following treatment with $100 \mu \mathrm{g} / \mathrm{ml} \mathrm{AFC} \mathrm{for} 48 \mathrm{~h}$ with or without IGF-I pretreatment (50 ng/ml) for $1 \mathrm{~h}$. (H) Quantification of the western blotting results, using actin as a loading control. All data are expressed as the mean \pm standard deviation from 3 independent experiments in triplicate. ${ }^{* * *} \mathrm{P}<0.01$ and ${ }^{* * * *} \mathrm{P}<0.001$ vs. vehicle control; ${ }^{\#} \mathrm{P}<0.05,{ }^{\# \#} \mathrm{P}<0.01$ and ${ }^{\# \# \#} \mathrm{P}<0.001$ vs. AFC alone. AFC, active fraction of clove; PI3K, phosphoinositide 3-kinase; mTOR, mechanistic target of rapamycin; IGF-I, Insulin-like growth factor-I; p-, phosphorylated.

evident in the Annexin V-FITC/PI double staining assay, in which combined treatment of AFC and 3-MA or BA increased apoptosis compared with AFC, 3-MA or BA alone in HCT-116 cells (Fig. 4E and F). These data suggest that autophagy 
induced by AFC exerted a suppressive effect on the apoptotic pathways of HCT-116 cells.

AFC inhibits the activation of the PI3K/Akt/mTOR signaling pathway in HCT-116 cells. It has been well documented that the PI3K/Akt/mTOR signaling pathway serves a key role in regulating both apoptosis and autophagy through divergent pathways (39). Therefore, the effect of AFC on the PI3K/Akt/mTOR signaling pathway in HCT-116 cells was investigated by western blotting. Treatment with AFC inhibited PI3K phosphorylation, decreased the levels of phospho-Akt, and downregulated phospho-mTOR in a dose-dependent manner (Fig. 5A). The ratios of p-Akt/Akt and $\mathrm{p}-\mathrm{mTOR} / \mathrm{mTOR}$ were significantly decreased following AFC treatment (Fig. 5B). LY294002 is a well-characterized inhibitor of PI3K (40), and the effect of combined AFC $(100 \mu \mathrm{g} / \mathrm{ml})$ and LY294002 $(10 \mu \mathrm{M})$ on the expression of p-Akt/Akt and p-mTOR/mTOR on HCT-116 cells was investigated by western blotting. The results revealed that the combination of AFC and LY294002 treatment was more effective in decreasing of the ratios of $\mathrm{p}-\mathrm{Akt} / \mathrm{Akt}(\mathrm{P}<0.001)$ and p-mTOR/mTOR $(\mathrm{P}<0.05)$ compared with AFC or LY294002 alone (Fig. 5C and D). Insulin-like growth factor-I (IGF-I), a PI3K activator, is capable of upregulating PI3K expression, as well as its downstream targets, Akt and mTOR (41). IGF-I treatment $(50 \mathrm{ng} / \mathrm{ml})$ significantly increased the phosphorylation of Akt and mTOR (Fig. 5E and F). When cells were pretreated with IGF-I $(50 \mathrm{ng} / \mathrm{ml})$, the effect of AFC was significantly attenuated. Furthermore, significant differences in the expression of the LC3-II/LC3-I, cleaved-PARP/PARP and cleaved-caspase-3/procaspase-3 ratios were observed between AFC treatment alone and the combination of AFC and IGF-I (Fig. 5G and H). These data indicate that the effect of AFC on induction of apoptosis and autophagy is associated with inhibition of the PI3K/Akt/mTOR signaling pathway.

\section{Discussion}

In the present study, the antitumor effect of AFC was investigated in human colorectal cancer cells. It was demonstrated that AFC inhibited cell proliferation and apoptosis and induced autophagy in a concentration- and time-dependent manner (Figs. 2-4). The effect of AFC on induction of apoptosis and autophagy was demonstrated to occur via inhibition of the PI3K/Akt/mTOR signaling pathway (Fig. 5). Furthermore, autophagy induced by AFC was demonstrated to suppress apoptotic pathways, and inhibition of autophagy by autophagic inhibitors, 3-MA and BA, enhanced the effects of AFC on cytotoxicity and apoptosis of HCT-116 cells (Fig. 4).

In our previous study, two active components of AFC, OA and Eugenol, were identified (12). OA has been demonstrated to exhibit anticancer efficacy against various types of human cancer cells $(12,42,43)$. Our previous study indicated that treatment of human pancreatic pan-28 cancer cells with OA induced apoptosis via a mitochondrially-mediated apoptotic pathway (13). It was also demonstrated that OA is able to induce protective autophagy in multiple types of cancer cells (30). In the present study, it was indicated that AFC-induced autophagy decreased its effect on induction of apoptosis in human HCT-116 cancer cells. Eugenol has also been demonstrated to possess moderate antitumor activity $(44,45)$, and to trigger apoptosis of breast cancer cells through E2F1/survivin downregulation (46). The combination of myricetin and methyl Eugenol enhanced the anticancer activity of cisplatin against HeLa cervical cancer cells (47). However, whether a synergistic effect of anticancer activity exists of OA and Eugenol remains unclear and requires further investigation. AFC may contain other anticancer components. Studies are on-going in our laboratory to address the complicated mechanism of the anticancer activity of clove.

Clove is traditionally believed in Chinese medicine to aid gastrointestinal function and to alleviate pain, and historically used to treat nausea, gastric spasm and sore throat (48). In a previous study it was demonstrated that oral administration of aqueous clove (100 $\mu \mathrm{l} / \mathrm{mouse} /$ day for 21 weeks) decreased the incidence of tumor development by $>50 \%$ in a mouse model of benzo[a]pyrene (BP)-induced lung carcinogenesis, and that the chemo-preventive effect of clove may be due to inhibition of anti-apoptotic gene expression, including that of $\mathrm{Bcl}-2$, VEGFA and CD44 (10). Our previous study also revealed that clove extracts were capable of inducing apoptosis via mitochondrial pathways in a number of cancer cell lines (12). Considering its low toxicity and its effectiveness, AFC has potential for development as a novel anticancer agent.

In the present study, AFC treatment was demonstrated to enhance autophagy in HCT-116 cells in a dose- and time-dependent manner. Autophagy has been indicated to be induced by anticancer drugs during the induction of apoptosis. Therefore, inducing autophagy-associated cell death of cancer cells may be useful in cancer treatment (49-52). An extract from the tuber of Amorphaphallus was reported to suppress the growth of proliferation of SGC-7901 and AGS cancer cells by induction of apoptosis and autophagy (53). Fenugreek extract also displayed anticancer effects through induction of autophagy and autophagy-associated death in human $\mathrm{T}$ lymphoma jurkat cells (54). The present study suggests that AFC extracts may be used in combination with classical chemotherapeutic agents to achieve an optimized outcome in the treatment of cancer.

In conclusion, the data from the present study indicate that AFC was able to induce typical apoptosis and autophagy in human colorectal cancer HCT-116 cells. Furthermore, the autophagy inhibitors, 3-MA and BA, potentiated the proapoptotic activity of AFC in HCT-116 cells. AFC also inhibited the phosphorylation of members of the PI3K/Akt/mTOR signaling pathway. These data may provide scientific rationale for improving the existing understanding of the anticancer mechanism of clove and to further develop AFC as a promising novel anticancer agent used alone or in combination with other chemotherapeutic agents for the treatment of colorectal cancer.

\section{Acknowledgements}

Not applicable.

\section{Funding}

The present study was supported by grants from the National innovative drug development projects of China (grant no.014ZX-09102043-001), National Natural Science Foundation 
of China (grant nos. 81302906, 81273550 and 41306157), and the Distinguished Professor Research Startup Funding (SC and XKL) from Southwest Medical University. This study was also supported in part by the grants from Sichuan Sci. and Tech Dept., China (grant nos. 2017SZ0201 and 17GJHZ0074).

\section{Availability of data and materials}

All data generated or analyzed during this study are included in this published article.

\section{Authors' contributions}

ML, SC and XL designed the experiments and analysed the data. GZ, DZ, WA and HL performed the experiments. ML, GZ, SC and XL wrote the manuscript. The final version of the manuscript has been read and approved by all authors.

\section{Ethics approval and consent to participate}

Not applicable.

\section{Patient consent for publication}

Not applicable.

\section{Competing interests}

The authors declare that the research was conducted in the absence of any commercial or financial relationships that could be construed as a potential conflict of interest.

\section{References}

1. Brouquet A and Nordlinger B: Metastatic colorectal cancer outcome and fatty liver disease. Nat Rev Gastroenterol Hepatol 10: 266-267, 2013.

2. Kuipers EJ, Rösch T and Bretthauer M: Colorectal cancer screening - optimizing current strategies and new directions. Nat Rev Clin Oncol 10: 130-142, 2013.

3. Schmoll HJ and Stein A: Colorectal cancer in 2013: Towards improved drugs, combinations and patient selection. Nat Rev Clin Oncol 11: 79-80, 2014.

4. Miller KD, Siegel RL, Lin CC, Mariotto AB, Kramer JL, Rowland JH, Stein KD, Alteri R and Jemal A: Cancer treatment and survivorship statistics, 2016. CA Cancer J Clin 66: 271-289, 2016.

5. Tanko Y, Mohammed A, Okasha MA, Umar AH and Magaji RA: Anti-nociceptive and anti-inflammatory activities of ethanol extract of Syzygium aromaticum flower bud in Wistar rats and mice. Afr J Tradit Complement Altern Med 5: 209-212, 2008.

6. Han X and Parker TL: Anti-inflammatory activity of clove (Eugenia caryophyllata) essential oil in human dermal fibroblasts. Pharm Biol 55: 1619-1622, 2017.

7. Aboubakr HA, Nauertz A, Luong NT, Agrawal S, El-Sohaimy SA, Youssef MM and Goyal SM: In vitro antiviral activity of clove and ginger aqueous extracts against Feline calicivirus, a surrogate for human norovirus. J Food Prot 79: 1001-1012, 2016.

8. Abd El Azim MHM, El-Mesallamy AMD, El-Gerby M and Awad A: Anti-tumor, antioxidant and antimicrobial and the phenolic constituents of clove flower Buds (Syzygiumaromaticum). J Microb Biochem Technol 10: s8-s007, 2014.

9. Gülçin I, Şat G, Beydemir S, Elmastaş M and Küfrevioğlu I: Comparison of antioxidant activity of clove (Eugenia caryophylata Thunb.) buds and lavender (Lavandulastoechas L.). Food Chem 87: 393-400, 2004.

10. Banerjee S,Panda CK and Das S: Clove (Syzygium aromaticum L.), a potential chemopreventive agent for lung cancer. Carcinogenesis 27: $1645-1654,2006$.
11. Kubatka P, Uramova S, Kello M, Kajo K, Kruzliak P, Mojzis J, Vybohova D, Adamkov M, Jasek K, Lasabova Z, et al: Antineoplastic effects of clove buds (Syzygium aromaticum L.) in the model of breast carcinoma. J Cell Mol Med 21: 2837-2851, 2017.

12. Liu H, Schmitz JC, Wei J, Cao S, Beumer JH, Strychor S, Cheng L, Liu M, Wang C, Wu N, et al: Clove extract inhibits tumor growth and promotes cell cycle arrest and apoptosis. Oncol Res 21: 247-259, 2014.

13. Wei J, Liu M, Liu H, Wang H, Wang F, Zhang Y, Han L and Lin X: Oleanolic acid arrests cell cycle and induces apoptosis via ROS-mediated mitochondrial depolarization and lysosomal membrane permeabilization in human pancreatic cancer cells. J Appl Toxicol 33: 756-765, 2013.

14. Ameisen JC: On the origin, evolution, and nature of programmed cell death: A timeline of four billion years. Cell Death Differ 9: 367-393, 2002.

15. Gerl R and Vaux DL: Apoptosis in the development and treatment of cancer. Carcinogenesis 26: 263-270, 2005.

16. 16. Elmore S: Apoptosis: A review of programmed cell death. Toxicol Pathol 35: 495-516, 2007.

17. Putcha GV, Harris CA, Moulder KL, Easton RM, Thompson CB and Johnson EM Jr: Intrinsic and extrinsic pathway signaling during neuronal apoptosis: Lessons from the analysis of mutant mice. J Cell Biol 157: 441-453, 2002.

18. Pistritto G, Trisciuoglio D, Ceci C, Garufi A and D'Orazi G: Apoptosis as anticancer mechanism: Function and dysfunction of its modulators and targeted therapeutic strategies. Aging (Albany NY) 8: 603-619, 2016.

19. Apel A, Zentgraf H, Büchler MW and Herr I: Autophagy-A double-edged sword in oncology. Int J Cancer 125: 991-995, 2009.

20. Liu J, Zhang Y, Qu J, Xu L, Hou K, Zhang J, Qu X and Liu Y: $\beta$-Elemene-induced autophagy protects human gastric cancer cells from undergoing apoptosis. BMC Cancer 11: 183, 2011.

21. White E: The role for autophagy in cancer. J Clin Invest 125: 42-46, 2015.

22. Kimmelman AC and White E: Autophagy and tumor metabolism. Cell Metab 25: 1037-1043, 2017.

23. Zarzynska JM: The importance of autophagy regulation in breast cancer development and treatment. BioMed Res Int 2014: 710345, 2014.

24. Li JP, Yang YX, Liu QL, Pan ST, He ZX, Zhang X, Yang T, Chen XW, Wang D, Qiu JX, et al: The investigational Aurora kinase A inhibitor alisertib (MLN8237) induces cell cycle G2/M arrest, apoptosis, and autophagy via p38 MAPK and Akt/mTOR signaling pathways in human breast cancer cells. Drug Des Devel Ther 9: 1627-1652, 2015.

25. Nagelkerke A, Bussink J, Geurts-Moespot A, Sweep FC and Span PN: Therapeutic targeting of autophagy in cancer. Part II: Pharmacological modulation of treatment-induced autophagy. Semin Cancer Biol 31: 99-105, 2015.

26. Shimizu T, Tolcher AW, Papadopoulos KP, Beeram M, Rasco DW, Smith LS, Gunn S, Smetzer L, Mays TA, Kaiser B, et al: The clinical effect of the dual-targeting strategy involving $\mathrm{PI} 3 \mathrm{~K} / \mathrm{AKT} / \mathrm{mTOR}$ and RAS/MEK/ERK pathways in patients with advanced cancer. Clin Cancer Res 18: 2316-2325, 2012.

27. Porta C, Paglino C and Mosca A: Targeting PI3K/Akt/mTOR signaling in cancer. Front Oncol 4: 64, 2014.

28. Zhirnov OP and Klenk HD: Control of apoptosis in influenza virus-infected cells by up-regulation of Akt and p53 signaling. Apoptosis 12: 1419-1432, 2007.

29. Roper J, Richardson MP, Wang WV, Richard LG, Chen W, Coffee EM, Sinnamon MJ, Lee L, Chen PC, Bronson RT, et al: The dual PI3K/mTOR inhibitor NVP-BEZ235 induces tumor regression in a genetically engineered mouse model of PIK3CA wild-type colorectal cancer. PLoS One 6: e25132, 2011.

30. Liu J, Zheng L, Zhong J, Wu N, Liu G and Lin X: Oleanolic acid induces protective autophagy in cancer cells through the JNK and mTOR pathways. Oncol Rep 32: 567-572, 2014.

31. Yang S, Zhao Q, Xiang H, Liu M, Zhang Q, Xue W, Song B and Yang S: Antiproliferative activity and apoptosis-inducing mechanism of constituents from Toona sinensis on human cancer cells. Cancer Cell Int 13: 12, 2013.

32. Wlodkowic D, Telford W, Skommer J and Darzynkiewicz Z: Apoptosis and beyond: Cytometry in studies of programmed cell death. Methods Cell Biol 103: 55-98, 2011.

33. Klionsky DJ, Abdelmohsen K, Abe A, Abedin MJ, Abeliovich H, Acevedo Arozena A, et al: Guidelines for the use and interpretation of assays for monitoring autophagy (3rd edition). Autophagy 12: 1-222, 2016. 
34. Liang XH, Jackson S, Seaman M, Brown K, Kempkes B, Hibshoosh $\mathrm{H}$ and Levine B: Induction of autophagy and inhibition of tumorigenesis by beclin 1. Nature 402: 672-676, 1999.

35. Xu ZX, Liang J, Haridas V, Gaikwad A, Connolly FP, Mills GB and Gutterman JU: A plant triterpenoid, avicin D, induces autophagy by activation of AMP-activated protein kinase. Cell Death Differ 14: 1948-1957, 2007.

36. Wu YT, Tan HL, Shui G, Bauvy C, Huang Q, Wenk MR, Ong CN, Codogno P and Shen HM: Dual role of 3-methyladenine in modulation of autophagy via different temporal patterns of inhibition on class I and III phosphoinositide 3-kinase. J Biol Chem 285: 10850-10861, 2010.

37. Klionsky DJ, Baehrecke EH, Brumell JH, Chu CT, Codogno P, Cuervo AM, et al: A comprehensive glossary of autophagyrelated molecules and processes (2nd edition). Autophagy 7 : 1273-1294, 2011

38. Periyasamy-Thandavan S, Jiang M, Wei Q, Smith R, Yin XM and Dong Z: Autophagy is cytoprotective during cisplatin injury of renal proximal tubular cells. Kidney Int 74: 631-640, 2008.

39. Shao X, Lai D, Zhang L and Xu H: Induction of autophagy and apoptosis via PI3K/AKT/TOR pathways by azadirachtin A in spodopteralitura cells. Sci Rep 6: 5482, 2016

40. Cheng Y, Diao D, Zhang H, Guo Q, Wu X, Song Y and Dang C: High glucose-induced resistance to 5-fluorouracil in pancreatic cancer cells alleviated by 2 -deoxy-D-glucose. Biomed Rep 2 : 188-192, 2014

41. Povsic TJ, Kohout TA and Lefkowitz RJ: $\beta$-arrestin1 mediates insulin-like growth factor 1 (IGF-1) activation of phosphatidylinositol 3-kinase (PI3K) and anti-apoptosis. J Biol Chem 278 51334-51339, 2003.

42. Li H, He N, Li X, Zhou L, Zhao M, Jiang H and Zhang X: Oleanolic acid inhibits proliferation and induces apoptosis in NB4 cells by targeting PML/RAR $\alpha$. Oncol Lett 6: 885-890, 2013

43. Shanmugam MK, Dai X, Kumar AP, Tan BK, Sethi G and Bishayee A: Oleanolic acid and its synthetic derivatives for the prevention and therapy of cancer: Preclinical and clinical evidence. Cancer Lett 346: 206-216, 2014.

44. Ghosh R, Nadiminty N, Fitzpatrick JE, Alworth WL, Slaga TJ and Kumar AP: Eugenol causes melanoma growth suppression through inhibition of E2F1 transcriptional activity. J Biol Chem 280: 5812-5819, 2005

45. Slamenová D, Horváthová E, Wsólová L, Sramková M and Navarová J: Investigation of anti-oxidative, cytotoxic, DNA-damaging and DNA-protective effects of plant volatiles eugenol and borneol in human-derived HepG2, Caco-2 and VH10 cell lines. Mutat Res 677: 46-52, 2009.
46. Al-Sharif I, Remmal A and Aboussekhra A: Eugenol triggers apoptosis in breast cancer cells through E2F1/survivin downregulation. BMC Cancer 13: 600, 2013.

47. Yi JL, Shi S, Shen YL, Wang L, Chen HY, Zhu J and Ding Y: Myricetin and methyl eugenol combination enhances the anticancer activity, cell cycle arrest and apoptosis induction of cis-platin against HeLa cervical cancer cell lines. Int J Clin Exp Pathol 8: 1116-1127, 2015

48. Pourgholami MH, Kamalinejad M, Javadi M, Majzoob S and Sayyah M: Evaluation of the anticonvulsant activity of the essential oil of Eugenia caryophyllata in male mice. J Ethnopharmacol 64: 167-171, 1999.

49. Amaravadi RK, Yu D, Lum JJ, Bui T, Christophorou MA, Evan GI, Thomas-Tikhonenko A and Thompson CB: Autophagy inhibition enhances therapy-induced apoptosis in a Myc-induced model of lymphoma. J Clin Invest 117: 326-336, 2007.

50. Chresta CM, Davies BR, Hickson I, Harding T, Cosulich S, Critchlow SE, Vincent JP, Ellston R, Jones D, Sini P, et al: AZD8055 is a potent, selective, and orally bioavailable ATP-competitive mammalian target of rapamycin kinase inhibitor with in vitro and in vivo antitumor activity. Cancer Res 70: 288-298, 2010.

51. Li X and Fan Z: The epidermal growth factor receptor antibody cetuximab induces autophagy in cancer cells by downregulating HIF-1alpha and Bcl-2 and activating the beclin $1 / \mathrm{hVps} 34$ complex. Cancer Res 70: 5942-5952, 2010.

52. Sasaki K, Tsuno NH, Sunami E, Tsurita G, Kawai K, Okaji Y, Nishikawa T, Shuno Y, Hongo K, Hiyoshi M, et al: Chloroquine potentiates the anti-cancer effect of 5-fluorouracil on colon cancer cells. BMC Cancer 10: 370, 2010.

53. Chen X, Yuan LQ, Li LJ, Lv Y, Chen PF and Pan L: Suppression of gastric cancer by extract from the tuber of amorphophallus konjac via induction of apoptosis and autophagy. Oncol Rep 38: 1051-1058, 2017.

54. Al-Daghri NM, Alokail MS, Alkharfy KM, Mohammed AK, Abd-Alrahman SH, Yakout SM, Amer OE and Krishnaswamy S: Fenugreek extract as an inducer of cellular death via autophagy in human T lymphoma Jurkat cells. BMC Complement Altern Med 12: 202, 2012. 